\title{
SELF-EFFICACY IN POSITIVE SEXUAL BEHAVIOR AMONG STUDENTS PARTICIPATING IN THE CENTER FOR INFORMATION AND COUNSELING OF REPRODUCTIVE HEALTH IN MADIUN
}

\author{
Haryadi, Heni Eka Puji Lestari, Nissa Kusariana \\ Schools of Health Sciences Bhakti Husada Mulia, Madiun, East Java
}

\begin{abstract}
Background: The study aimed to determine the effectiveness of the Center for Information and Counseling of Reproductive Health in improving selfefficacy in positive social behavior among university students Madiun.

Subjects and Method: This was an analytic observational study with cohort retrospective design. This study was conducted at Bhakti Husada Mulya School of Health Sciences, Madiun, East Java. A sample of 105 university students were selected for this study using fixed exposure sampling. This sample consisted of 35 students who participated and 70 students who did not participate in the Center for Information and Counseling of Reproductive Health. The purpose of this center was to develop positive sexual behavior among university students. The dependent variable was self-efficacy in sexual behavior. The independent variable was participation in the Center for Information and Counseling of Reproductive Health. The data were collected using questionnaire and analyzed using t-test.

Results: Self-efficacy in sexual behavior among students who participated in the center was higher $($ mean $=49.69 ; \mathrm{SD}=6.66)$ than those who did not participate in the center (mean $=44.41 ; \mathrm{SD}=10.09$ ), and it was statistically significant $(\mathrm{p}=0.006)$.

Conclusion: Participation in the Center for Information and Counseling of Reproductive Health can enhance self-efficacy in positive sexual behavior among students.
\end{abstract}

Keywords: sexual behavior, self efficacy, Center for Information and Counseling of Reproductive Health, student

Correspondence: Nissa Kusariana. Schools of Health Sciences Bhakti Husada Mulia, Madiun, East Java. Email: nissakusariana@gmail.com 